\title{
Analisis Kesalahan Fonem Pada Spanduk di Jalan Daan Mogot Jakarta Barat-Tangerang
}

\author{
Irma Afriyani ${ }^{1}$, Ira Anisa Purawinangun ${ }^{2}$ \\ Universitas Muhammadiyah Tangerang \\ irmaafriyanifm24@gmail.com
}

\begin{abstract}
Abstrak
Kesalahan fonologi dalam bahasa tulis kelihatannya berupa kesalahan kecil, tetapi dapat menyebabkan munculnya makna yang berbeda. Penelitian ini bertujuan untuk mendeskripsikan kesalahan fonem pada spanduk di jalan Daan Mogot Jakarta Barat-Tangerang. Metode untuk menganalis data yang digunakan dengan menggunakan metode catat dan baca Metode yang digunakan dalam penelitian metode kualitatif deskriptif yaitu objek penelitian berupa struktur bahasa yang tergolong sebagai data kualitatif atau data bukan angka, maka data ini dianalaisis secara kualitatif deskriptif. Hasil penelitan menunjukkan bahwa kesalahan fonologi terhadap spanduk di jalan Daan Mogot Jakarta BaratTangerang dibagi menjadi 3 aspek, yaitu pengurangan fonem yaitu pada fonem /e/ dan fonem $/ \mathrm{k} /$, penambahan fonem yaitu pada fonem $/ \mathrm{l} /$ dan fonem $/ \mathrm{h} / \mathrm{dan}$ penggantian fonem yaitu fonem /a/ diganti fonem /e/ dan fonem /u/ diganti /o/.
\end{abstract}

Kata kunci : kesalahan fonem, spanduk, jalan

\section{A. Pendahuluan}

Bahasa sejak dini telah memberikan peranan penting bagi perkembangan manusia. Bahasa sebagai alat komunikasi atau interaksi yang dihasilkan oleh alat ucap manusia, dalam hal ini komunikasi dilakukan dengan cara lisan maupun tulisan. Jika komunikasi tersebut dilakukan secara tulisan, tidak ada alat ucap di dalamnya. Jika komunikasi itu dilakukan dengan lisan, alat ucap memegang peranan yang sangat penting. Belajar bahasa menjadi kewajiban bagi semua orang, setiap bahasa perlu dilestarikan keberadaannya. Dengan belajar bahasa, berarti juga belajar membudidayakan diri sendiri dan membentuk diri menjadi manusia yang luhur. 
Penulisan spanduk masih banyak memiliki kesalahan penggunaan bahasa Indonesia dengan baik dan benar. Baik artinya sesuai konteks yang digunakan dengan norma kemasyarakatan yang berlaku dan benar artinya bahasa yang penulisannya sesuai dengan kaidah bahasa Indonesia. Inilah bentuk kesalahankesalahan yang perlu dianalisis untuk melakukan perbaikan ke depan. Kesalahankesalahan berbahasa ini terbagi dalam semua aspek kebahasaan, baik itu aspek fonologi, morfologi, sintaksis, semantik, dan bahkan wacana sekalipun.

Kesalahan berbahasa Indonesia dalam tataran fonologi dapat terjadi baik pengguanaan bahasa secara lisan maupaun tertulis. Sebagian besar kesalahan berbahasa Indonesia berkaitan dengan penulisan yang menyangkut dalam tataran fonologi. Kesalahan fonologi dalam bahasa tulis kelihatannya berupa kesalahan kecil, tetapi dapat menyebabkan munculnya makna yang berbeda. Dalam fonologi kesalahan berbahasa meliputi perubahan fonem, penghilang fonem, dan penambahan fonem vokal maupun konsonan. Sistem penulisan bahasa Indonesia yang dipakai selama ini mengikuti ejaan fonemis, setiap satu fonem dilambangkan satu huruf.

Dengan demikian perlu dilakukan analisis kesalahan berbahasa tataran fonologi pada spanduk, sehingga semua kalangan masyarakat menyadari dan bertindak mengevaluasi dengan mencari kesalahan berbahasa pada spanduk. Dalam hal ini kesalahan berbahasa pada spanduk sangat penting untuk diteliti, maka berdasarkan latar belakang masalah di atas peneliti akan mengkaji lebih jauh lagi dalam bentuk skripsi yang berjudul "Analisis Kesalahan Fonem Pada Spanduk di Jalan Daan Mogot Jakarta Barat-Tangerang”.

Tujuan penelitian ini yaitu 1) mendeskripsikan kesalahan karena penambahan fonem pada spanduk di jalan Daan Mogot Jakarta Barat-Tangerang; 2) mendeskripsikan kesalahan karena penghilangan fonem pada spanduk di Jalan Daan Mogot Jakarta Barat-Tangerang; 3) mendeskripsikan kesalahan karena perubahan fonem pada spanduk di jalan Daan Mogot Jakarta Barat-Tangerang.

\section{B. Kajian Pustaka}


Spanduk merupakan sebuah media cetak yang digunakan untuk memperkenalkan atau membuat masyarakat umum mengetahui suatu informasi berupa produk apapun. Hakikatnya spanduk adalah sebuah kain yang membentang berisikan tulisan dan bergambar yang biasanya berada di tepi jalan sebagai media untuk mempromosikan sebuah produk pada masyarakat umum.

Menurut Kertamukti (2015) "Iklan dipapan reklame dirancang untuk memperkenalkan nama merek sebagai tujuan utamanya, walaupun periklanan di papan reklame merupakan bagian tersbesar dari periklanan luar rumah, berbeda dengan televisi, majalah dan radio yang diterima dirumah" (h. 139). Fungsi spanduk adalah untuk mempertahankan kualitas produk yang sudah ditawarkan kepada konsumen agar tidak hilang dari pasaran dan dapat menjaga efektivitasnya.

Spanduk membentuk permintaan selektif untuk suatu merek tertentu dilakukan pada tahap kompetetif dengan membentuk preferensi merek, mendorong ahli merek, dan membujuk pembeli untuk membeli sekarang dan menerima, mencoba/ mensimulasikan penggunaan produk. Dalam penggunaan bahasanya spanduk biasanya menggunakan persuasi.

Keraf (2012) mendefinisikan bahwa "Persuasif adalah suatu seni verbal yang bertujuan untuk meyakinkan seseoarang agar melakukan sesuatu yang dikehendaki pembicara pada waktu ini atau waktu yang akan datang” (h. 118). Untuk meyakinkan apa yang dipersuasikan, pembicara atau penulis harus menimbulkan kepercayaan pada para pembaca. Kepercayaan merupakan unsur utama dalam persuasi, oleh sebab itu kalimat spanduk didalamnya ada sebuah persuasi.

Pada hakikatnya kesalahan merupakan perilaku menyimpang yang tidak sesuai dengan norma dan tidak menurut dengan aturan yang telah ditentukan. Hal ini dapat terjadi pada pemakaian bahasa dalam kehidupan sehari-hari, baik dari bahasa lisan maupun bahasa tulis.

Tarigan dan Djago (2011) menayatakan bahwa "Kesalahan adalah gambaran terahadap pemahaman siswa terhadap sistem bahasa yang sedang dipelajarinya" 
(h.68). Kesalahan yakni bila tahap pemahaman siswa terhadap sistem bahasa yang sedang dipelajarinya ternyata kurang maka kesalahan sering terjadi, dan kesalahan akan berkurang apa bila tahap pemahaman semakin meningkat.

Pendapat lain menurut Setyawati (2010) bahwa "Kesalahan adalah sebuah proses yang didasarkan pada analisis kesalahan orang yang sedang belajar dengan objek yaitu bahasa yang sudah ditargetkan" (h.16). Kesalahan bahasa lebih menekankan Bahasa ibu sebagai target dalam proses belajar, kemudian bahasa nasional dan bahasa asing untuk itu perlu memahaminya dalam proses belajar.

\section{Metodologi Penelitian}

Penelitian ini menggunakan metode deskriptif, yang datanya dikumpulkan berupa kata-kata, gambar, dan bukan angka-angka. Data tersebut mungkin berasal dari naskah wawancara, catatan lapangan, foto, videotape, dokumen pribadi, catatan, dan dokumen resmi lainnya. Pada penulisan laporan, peneliti menganalisis data yang sangat kayadan sejauh mungkin dalam bentuk aslinya, setiap bagian ditelaah satu demi satu.

Sumber data penelitian merupakan faktor penting yang menjadi pertimbangan dalam penentuan metode pengumpulan data, selain jenis data. Sumber data dalam penelitian ini adalah spanduk yang berada di sekitar Jalan Daan Mogot Jakarta Barat - Tangerang. Peneliti memilih spanduk sebagai sumber data karena ingin meneliti kesalahan fonologi yang ada pada spanduk tersebut. Sedangkan data yang menjadi objek penelitian ini adalah bahasa yang digunakan dalam spanduk.

Langkah-langkah yang dilakukan peneliti dengan menggunakan sumber data yaitu: 1) peneliti mencari serta membaca tulisan yang ada pada spanduk di Jalan Daan Mogot Jakarta Barat - Tangerang; 2) peneliti memahami segala bentuk penulisan yang terdapat pada spanduk di Jalan Daan Mogot Jakarta Barat Tangerang; 3) peneliti memfoto tulisan yang terdapat dalam spanduk tersebut; 4) peneliti mengklasifikasikan penggunaan fonem apakah termasuk ke dalam penambahan fonem, penghilang fonem, dan perubahan fonem. 
Data penelitian akan dianalisis melalui langkah-langkah yaitu 1) peneliti mengklasifikasikan bentuk kesalahaan penggunaan fonem pada spanduk yang berada di sekitar Jalan Daan Mogot Jakarta Barat-Tangerang; 2) data tersebut dianalisis dan dideskripsikan; dari analisis tersebut akan tergambar bentuk keslahan penggunaan fonem yang termasuk ke dalam penambahan fonem, peubahan fonem, dan penghilang fonem; 3) menarik kesimpulan berdasarkan hasil analisis data.

\section{Pembahasan}

Pada pembahasan ini, penulis akan membahas hasil pengamatan dan data hasil penelitian pada kesalahan fonem yang terdapat pada spanduk yang ada di Jalan Daan Mogot Jakarta Barat- Tangerang dapat dijabarkan sebagai berikut.

\section{Kesalahan pengurangan fonem}

Berdasarkan hasil penelitian dapat ditemukan pada kesalahan penambahan fonem vokal dan konsonan. Kesalahan tersebut sebagai berikut.

\section{a. Pengurangan Fonem}

\section{Contoh 1}

Spanduk yang terdapat kesalahan pengurang fonem vokal pada tiap kata yang ada sebagai berikut :

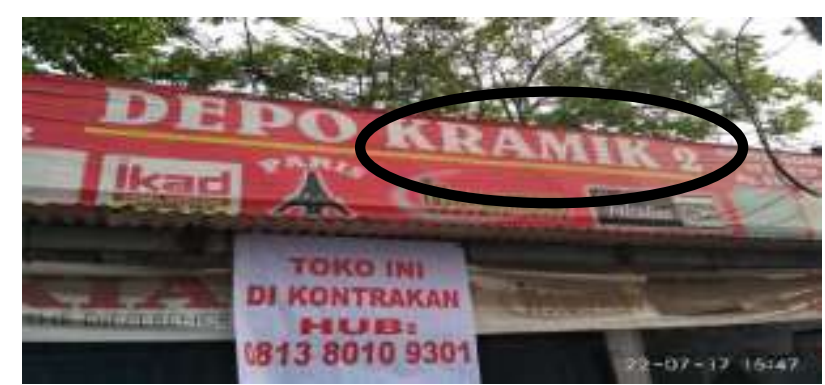

\section{Gambar 4.1}

Struktur kalimat yang ada pada penelitan ini, data tersebut menunjukkan terdapat penambahan fonem, fonem satuan terkecil yang bersifat fungsional mampu menunjukkan makna. Fonem tidak dapat berdiri sendiri karena belum mengandung arti. Dalam konteks ini kesalahan terjadi pada kata 'Kramik' yang seharusnya 'Keramik'. Jadi, terdapat pengurangan fonem /e/ pada kata 'kramik'. 
Kata 'Keramik' benda yang terbuat tanah liat yang dibakar, dicampur dengan mineral lain barang tembikar, yang biasanya dipakai sebagai lantai bangunan.

\section{Contoh 2}

Spanduk yang terdapat kesalahan penambahan fonem konsonan pada tiap kata yang ada sebagai berikut:

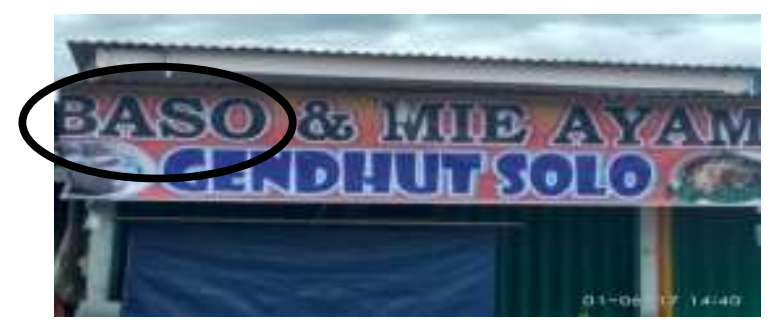

Gambar 4.2

Dalam struktur kalimat yang ada pada penelitan ini, data tersebut menunjukkan terdapat pengurangan fonem, fonem satuan terkecil yang bersifat fungsional mampu menunjukkan makna. Fonem tidak dapat berdiri sendiri karena belum mengandung arti. Dalam konteks ini kesalahan terjadi pada kata 'Baso' yang seharusnya 'Bakso'. Jadi, terdapat pengurangan fonem /k/ pada kata 'Baso'. Pengurangan yang tepat adalah 'Bakso' makanan yang terbuat dari daging, udang, ikan, yang dicincang dan dilumatkan bersama tepung kanji beserta bumbu penyedap lainnya.

\section{b. Penambahan Fonem}

\section{Contoh 3}

Spanduk yang terdapat kesalahan penghilang fonem konsonan pada tiap kata yang ada sebagai berikut:

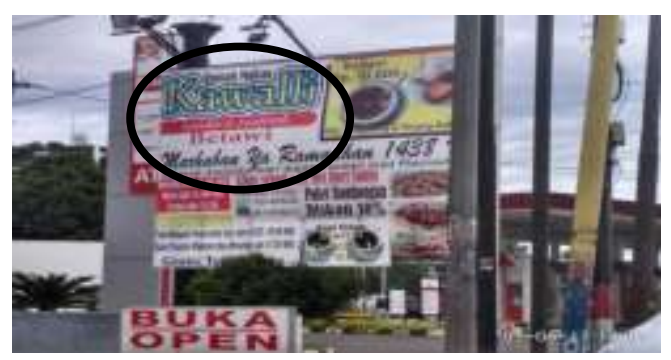

\section{Gambar 4.3}


Struktur kalimat yang ada pada penelitan ini, data tersebut menunjukkan terdapat penambahan fonem, fonem satuan terkecil yang bersifat fungsional mampu menunjukkan makna. Fonem tidak dapat berdiri sendiri karena belum mengandung arti. Dalam konteks ini kesalahan terjadi pada kata 'Kawalli' yang seharusnya 'Kawali'. Jadi, terdapat penambahan fonem konsonan /// pada kata 'Kawalli'. Penulisan yang tepat adalah 'Kawali' sebuah daerah yang termasuk ke dalam provinsi jawa barat berbatasan dengan Banjar dan Pangandaran.

\section{Contoh 2}

Spanduk yang terdapat kesalahan penghilang fonem konsonan pada tiap kata yang ada sebagai berikut:

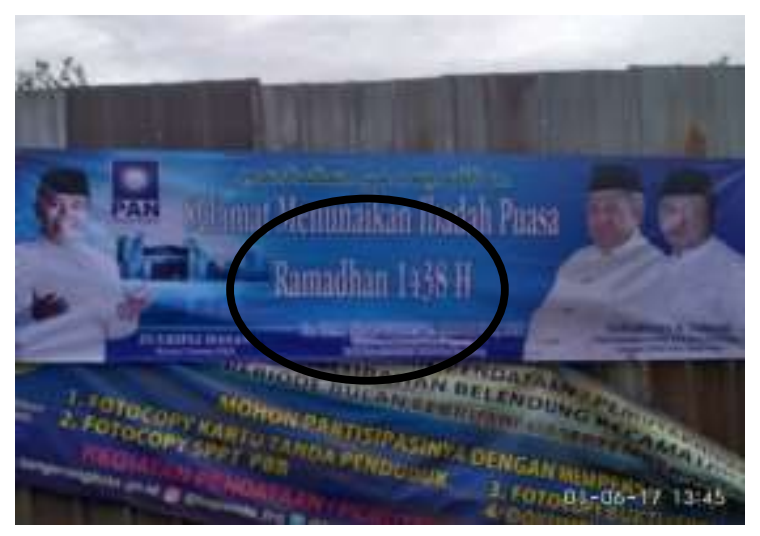

\section{Gambar 4.4}

Struktur kalimat yang ada pada penelitan ini, data tersebut menunjukkan terdapat penambahan fonem, fonem satuan terkecil yang bersifat fungsional mampu menunjukkan makna. Fonem tidak dapat berdiri sendiri karena belum mengandung arti. Dalam konteks ini kesalahan terjadi pada kata 'Ramadhan' yang seharusnya 'Ramadan'. Jadi, terdapat penghilang fonem konsonan $/ \mathbf{h} /$ pada kata 'Ramadhan'. Penulisan yang tepat adalah 'Ramadan' bulan ke 9 tahun Hijriah (29 atau 30 hari) pada bulan ini orang islam diwajibkan berpuasa.

\section{c. Penggantian Fonem}

Contoh 1 
Spanduk yang terdapat kesalahan perubahan fonem vokal pada tiap kata yang ada sebagai berikut:

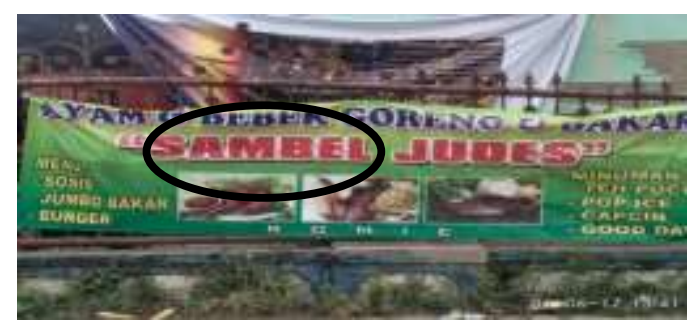

\section{Gambar 4.5}

Struktur kalimat yang ada pada penelitan ini, data tersebut menunjukkan terdapat perubahan fonem, fonem satuan terkecil yang bersifat fungsional mampu menunjukkan makna. Fonem tidak dapat berdiri sendiri karena belum mengandung arti. Dalam konteks ini kesalahan terjadi pada kata 'sambel' yang seharusnya 'sambal'. Jadi, terdapat perubahan fonem vokal /e/ menjadi /a/ pada kata 'Sambal'. Penulisan yang tepat adalah 'sambal' makanan penyedap yang dibuat dari cabai, garam, dan sebagainya yang ditumbuk, dihaluskan biasanya dimakan bersama nasi.

\section{Contoh 2}

Spanduk yang terdapat kesalahan perubahan fonem vokal pada tiap kata yang ada sebagai berikut:

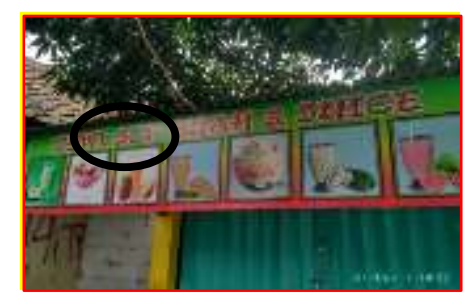

Gambar 4.6

Dalam struktur kalimat yang ada pada penelitan ini, data tersebut menunjukkan terdapat perubahan fonem, fonem satuan terkecil yang bersifat fungsional mampu menunjukkan makna. Fonem tidak dapat berdiri sendiri karena belum mengandung arti. Dalam konteks ini kesalahan terjadi pada kata 'Sop' yang seharusnya 'Sup'. Jadi, terdapat perubahan fonem vokal /o/ menjadi /u/ pada kata 'Sop'. Dalam Kamus Besar Bahasa Indonesia yang tepat adalah 'Sup' sesuatu 
yang berkuah dengan berbagai macam sayuran maupun buah yang disajikan dalam minum atau masakan.

\section{E. Simpulan}

Berdasarkan hasil peneltian dan pembahasan, maka dapat disimpulkan bahwa kesalahan fonologi pada spanduk di jalan Daan Mogot Jakarta Barat Tangerang dibagi menjadi 3 aspek, yaitu pengurangan fonem yaitu pada fonem /e/ dan fonem $/ \mathrm{k} /$, penambahan fonem yaitu pada fonem $/ \mathrm{l} /$ dan fonem/h/ dan penggantian fonem yaitu fonem /a/ diganti fonem /e/ dan fonem /u/ diganti /o/.

\section{F. Daftar Pustaka}

Guntur Tarigan, H \& Tarigan, D. (2011). Pengajaran Analisis Kesalahan Berbahasa. Bandung: Angkasa

Kertamukti, Rama. (2015). Strategi Kreatif Dalam Periklanan. Jakarta: PT Raja Grafindo Persada

Keraf, Gorys. (2010). Argumentasi dan Narasi. Jakarta: Gramedia

Setyawati, Nanik. (2013). Analisis Kesalahan Berbahasa Indonesia. Surakarta: Yuma Pustaka 